\title{
THE EFFECTIVENESS OF A NOVEL STEAMING METHOD IN IMPROVING SMALL SCALE SOYBEAN DEHULLING
}

\author{
J. J. Mpagalile ${ }^{1 *}$, H. S. Laswai ${ }^{1}$, W. R. Ballegu ${ }^{1}$ and V. C. K. Silayo ${ }^{2}$
}

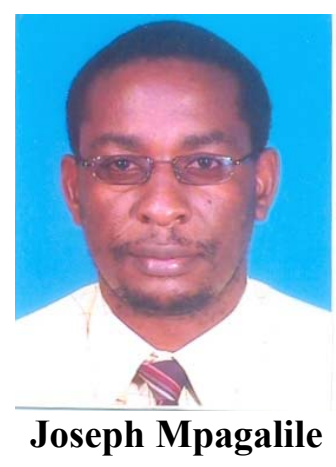

*Corresponding author email: jimpagalile@yahoo.com

${ }^{1}$ Department of Food Science and Technology, Sokoine University of Agriculture, P. O. Box 3006, Chuo Kikuu, Morogoro, Tanzania. Tel.: +255 (0)23 2604649.

${ }^{2}$ Department of Agricultural Engineering and Land Planning, Sokoine University of Agriculture, P. O. Box 3003, Chuo Kikuu, Morogoro, Tanzania.

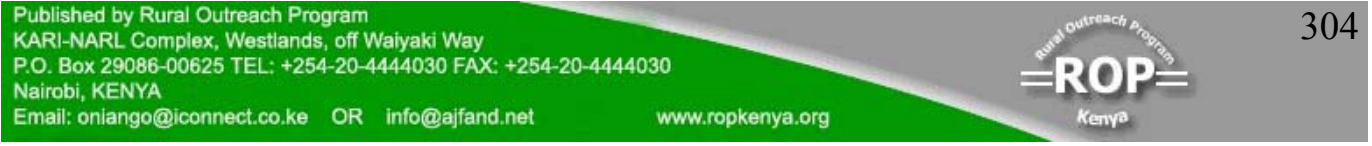




\section{ABSTRACT}

Locally grown Black (Ex Songea) and Bossier soybeans, Glycine max (L.) varieties were used in a study to determine the effect of steaming on soybean dehulling properties. Prior to carrying out the experiment, soybeans were sorted and cleaned. This was followed by the determination of oil content, weight per grain, bulk density and moisture content before conditioning the seeds ready for dehulling. Proximate analysis showed that the Black (Ex Songea) soybeans had an average oil content, weight per grain, bulk density and moisture content of $18.36 \%, 1.45 \mathrm{~g}, 738 \mathrm{~kg} / \mathrm{m}^{3}$ and $12.25 \%$ respectively. On the other hand, Bossier variety of soybeans were found to have an average oil content of $20.21 \%$, weight per grain of $1.95 \mathrm{~g}$, bulk density of 789 $\mathrm{kg} / \mathrm{m}^{3}$, and moisture content of $12.75 \%$. Steaming was done using a double pot steamer and was conducted at 5, 10 and 15 minutes interval followed by solar drying for 24 hours using unsteamed soybeans as a control. The steaming procedure involved placing $500 \mathrm{~g}$ of soybeans in the upper pot then tight fitting it on the lower pot that contained 4 litres of boiling water. Refilling of water was done every after 20 minutes of steaming to bring the water level to its original mark. After steaming, soybeans were dried in a cabinet solar drier capable of reaching temperatures in the range of 43$46^{\circ} \mathrm{C}$. The dehulling operation was carried out for 5 minutes using a Tangential Abrasive Dehulling Device (TADD) machine. The efficiency of steaming method was determined based on the dehulling effectiveness index $(\eta)$. Results showed that steaming followed by solar drying tends to significantly $(p<0.05)$ improve the dehulling qualities of both Bossier and Black (Ex Songea) soybean varieties when compared to unsteamed beans, which performed poorly with consistently higher breakage levels. The cotyledon recovery percentage for unsteamed Black (Ex Songea) beans was $68.35 \%$ compared to $82.20 \%$ for soybeans steamed for 15 minutes. Similarly, unsteamed Bossier soybeans had $74.75 \%$ recovery of cotyledons compared to $85.40 \%$ for those steamed for 15 minutes. Results from this study showed that steaming led to better performance in the dehuller for the Bossier soybean variety than the Black (Ex Songea) variety. The tested steaming method is simple and can be applied in rural areas as a preconditioning stage to improve soybeans processing prior to dehulling especially at small scale level.

Key words: soybean, steaming, abrasive, dehulling efficiency

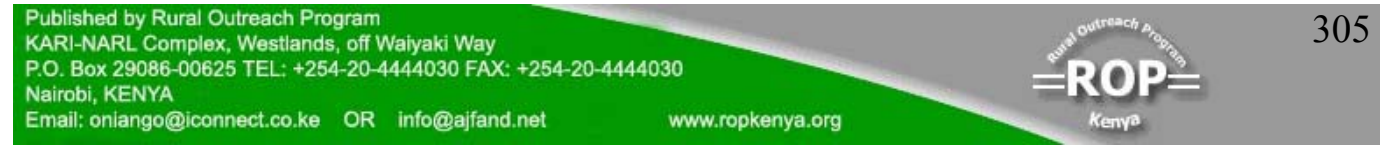




\section{INTRODUCTION}

Soybean, Glycine max (L.) is a legume crop that is increasingly becoming popular in sub-Saharan Africa. Soybean has high protein content $(\sim 40 \%)$ and superior amino acid profiles compared to other sources of plant proteins [1]. Compared to other protein-rich foods such as meat, fish and eggs, soybean is by far the cheapest. Soybean is an important protein supplement for starchy foods in countries like Tanzania, where the consumption of animal protein is estimated at only 11.5 $\mathrm{g} /$ capita/day [2]. This is roughly only $20 \%$ of the total protein requirement [3].

Soybean processing, however, has over the years been a major challenge to the acceptability and popularity of soybeans in Africa. This is mainly due to lack of simple and efficient small-scale soybean processing technologies suitable for farmers and processors in rural areas. One of the operations that pose a challenge for small scale soybean processing is dehulling, which as for many other grain crops, is a critical stage during processing. Phirke and Bhole [4] noted that dehulling quality is a function of both seed coat removal from cotyledons and the head splits yields. In Tanzania, soybean dehulling is commonly done using the wet method whereby soybeans are soaked or boiled for a prolonged period of time, cooled then rubbed using hands (between fingers) to loosen the hulls. Thereafter, the hulls are washed away using water. In this method, a lot of water is wasted, important nutrients are lost and proteins are denatured. Excessive use of water necessitates prolonged drying periods that adds extra costs. If drying is not done properly the cotyledons become mouldy, leading to inferior final products.

Attempts have been made to develop better dehulling methods for leguminous and non leguminous crops such as sorghum, canola, cowpeas and soybean [5]. These attempts have included studies on the preconditioning of the crops as well as design of better dehulling equipment such as those using abrasive surfaces [6,7]. The use of chemicals such as sodium bicarbonate and sodium chloride has been reported as well [8]. However, considerable loss of proteins, starch and vitamins is associated with these methods, thus making them unsuitable.

In addition, most of the developed methods favour medium to large scale operations leaving poor farmers with little or no option. Studies on rheological properties of soybeans during processing have also been reported. For example, investigation on fracture resistance of soybeans to compressive loading found that loading orientation and moisture content both had a significant effect on the force required to break the seed coats [9]. In another study, seed coat adhesion was measured by the force required to remove the seed coat from the cotyledon [10] and used to determine the dehulling time required for the grain to be exposed to abrasive surfaces. This study provided an insight into the relationship between cotyledon adhesion and grain splitting tendency in soybeans. In addition, a recent study also measured the force required to separate two soybean cotyledons as a function of the seed coat adhesion [4]. An attempt was made to measure seed coat adhesion and cotyledon adhesion

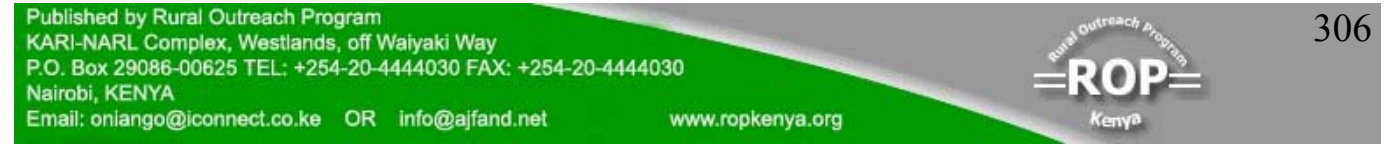


using a piezoelectric crystal cell transducer to determine ways in which dehulling of soybeans and related legumes can be simplified and thus increase efficiency.

Studies have also shown that heat treatment improves dehulling properties as it makes cotyledons resilient or plastic, whereas the seed coat becomes brittle and easily breaks when distorted by abrasive surface [11,12]. Nutritionally, the heat treatment of soybeans helps to inhibit some unwanted trypsins. This is beneficial to consumers as it renders more nutrients available to the body. In this study, we investigated the effectiveness of a novel soybean preconditioning technique using simple steaming equipment followed by solar drying, for use in small scale operations to dehull soybean varieties grown in Tanzania.

\section{MATERIALS AND METHODS}

\section{Source of raw materials}

The Bossier and Black (Ex Songea) soybean varieties used in this study were obtained from Peramiho village, Songea district in the southern Tanzania.

\section{Preparation of raw materials}

Soybeans were first sorted, cleaned and then weighed. Moisture and oil content were determined before conditioning the seeds ready for dehulling. A total of 100 soybean seeds were randomly selected from each variety and weighed in order to determine the average weight of a single seed. Figure 1 shows the steaming equipment used in this study that comprised two aluminium-cooking pots with one pot being tight fitted on the other. The upper pot had a diameter of $230 \mathrm{~mm}$ and its base was perforated with $3 \mathrm{~mm}$ holes. The lower pot had a $231 \mathrm{~mm}$ diameter and its base was intact as it was meant to hold the boiling water.

Steam was used to condition triplicate samples of soybeans for 5, 10 and 15 minutes. The steaming procedure involved placing $500 \mathrm{~g}$ of soybeans in the upper pot then tight fitting it on the lower pot that contained 4 litres of boiling water. Water in the lower pot was heated using an electric cooker to produce steam that was forced to pass through the punched holes to condition the soybeans. In order to prevent steam from escaping, the upper pot was tightly covered with a flat aluminium lid and held in place by placing weights on top. Make up water was added to the lower pot after every 20 minutes in order to keep the water level constant.

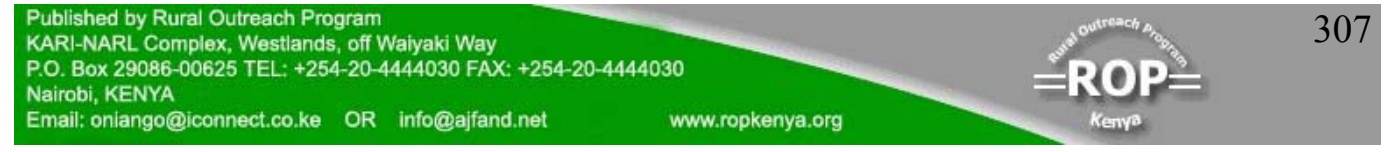




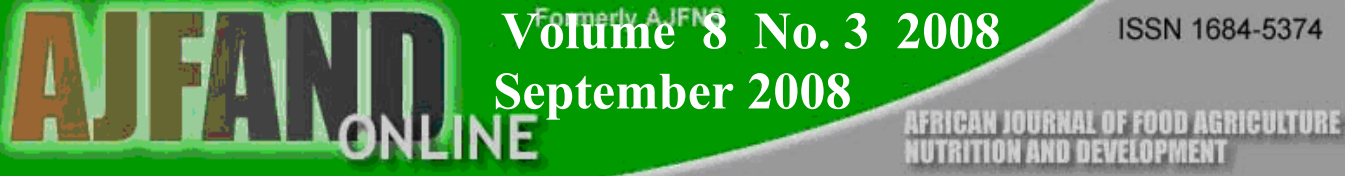

Figure 1: Steaming setup showing the arrangement of pots

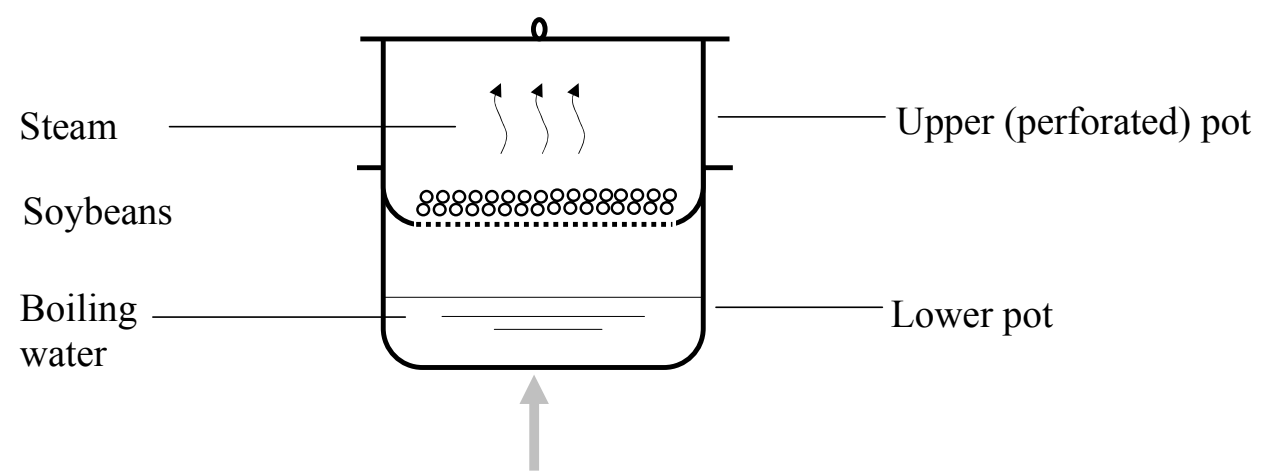

Heat

After steaming, soybeans were dried using a cabinet solar drier capable of reaching temperatures in the range of $43-46^{\circ} \mathrm{C}$. Steamed soybeans were spread on solar drier trays measuring $300 \mathrm{~mm} \times 300 \mathrm{~mm}$ and dried for a period of 8 hours for two consecutive days. The dried samples were then stored in sealed polyethylene bags before dehulling. Both steamed and unsteamed (control) beans were dehulled using a Tangential Abrasive Dehulling Device (TADD) described in [6] and [13]. The dehuller had a plate with eight cups each with a capacity to hold $64 \mathrm{~g}$ of grains. Dehulling was effected using a specialized sand paper that was fixed to the horizontal plate. A residence time of 3 minutes was used before manually removing the dehulled sample from the TADD machine. Cotyledons, undehulled soybeans, hulls and fines were separated and further analyzed. Moisture content was determined in an oven set at $130^{\circ} \mathrm{C}$ for 3 hours. The fat content was determined using the Soxhlet method [14].

\section{Determination of the dehulling efficiency}

The overall performance of the steaming method was determined based on the dehulling effectiveness that was determined using the dehulling effectiveness index ( $)$ [15]. The index was calculated using the formula indicated in equation 1.

$\eta=\left[\left(M_{c}+M_{h}\right)-\left(M_{u h}+M_{f}\right)\right] / M_{g}$

(Equation 1)

Where $M_{c}$ is the mass of cotyledon ( $g$ ), $M_{h}$ is the mass of removed hulls $(g), M_{u h}$ is the mass of undehulled soybeans $(\mathrm{g}), \mathrm{M}_{\mathrm{f}}$ is the mass of fines $(\mathrm{g})$ and $\mathrm{M}_{\mathrm{g}}$ is the mass of the sample before dehulling $(\mathrm{g})$. 
The weight of the cotyledon fraction, also referred to as an outturn, was also determined. Furthermore, the weights of the undehulled soybeans, hulls and fines were obtained and expressed as a percentage of the weight of the sample before dehulling. These parameters were used to explain the effectiveness of steaming. In addition, the system loss (\%) was determined by obtaining the difference between the weight of the products that came out of the dehuller to the sample weight that entered into the dehuller and was expressed as a percentage of the sample weight.

All experiments were conducted in a Completely Randomized Design (CRD) using three replicates. Analysis of variance of the two factors and interactions were applied to the different sets of data. Least significant differences were calculated by the Fishers test $(\mathrm{P}=0.05)$ and Duncan Multiple Range Test (DMRT) was used to separate the means.

\section{RESULTS}

The physical characteristics which included average bulk density, shape and size, oil and moisture content were determined in the laboratory and results are presented in Table 1. The bulk density of soybeans averaged $738 \mathrm{~kg} / \mathrm{cm}^{2}$ for Black (Ex Songea) and $789 \mathrm{~kg} / \mathrm{cm}^{2}$ for Bossier soybean. The beans from the Bossier variety were more spherical and larger in size compared to the Black (Ex Songea) soybeans, which were slightly elongated and smaller in size. The moisture content of the soybeans was $12.25 \%$ and $12.76 \%$ for the Bossier and Black (Ex Songea) varieties, respectively.

The results on the effect of steaming on dehulling properties of the two soybean varieties are summarized in Table 2. The cotyledon fraction (the outturn) ranged from $68.35 \%$ with no steaming to $82.20 \%$ after 15 minutes of steaming for Black (Ex Songea) soybeans. Similarly, Bossier variety generated $74.75 \%$ outturn with no steaming and $85.40 \%$ after steaming for 15 minutes. Also, Black (Ex Songea) variety led to $18.80 \%$ of undehulled fraction compared to $14.74 \%$ for Bossier variety when no steaming treatment was done. Hull fraction from Black variety (Ex Songea) was $11.65 \%$ after 15 minutes of steaming whereas same treatment led to $9.15 \%$ for Bossier. The fraction of fines ranged from $0.57 \%$ at no steaming to $0.91 \%$ after steaming for 15 minutes for Black variety (Ex Songea) whereas for Bossier variety the result was $0.68 \%$ at no steaming and $0.92 \%$ after steaming for 15 minutes.

Figure 2 shows the effect of steaming time (minutes) on the dehulling loss (\%). Results showed that for Black (Ex Songea) soybean, dehulling loss of 3.38\% was observed at no steaming but decreased to $2.61 \%, 3.04 \%$ and $2.64 \%$ at 5,10 and 15 minutes of steaming time, respectively. Similar results were observed for Bossier soybeans whereby a dehulling loss $1.52 \%$ was observed at no steaming, but increased to $2.31 \%, 2.21 \%$ and $2.23 \%$ at the corresponding steaming time of 5,10 and 15 minutes.

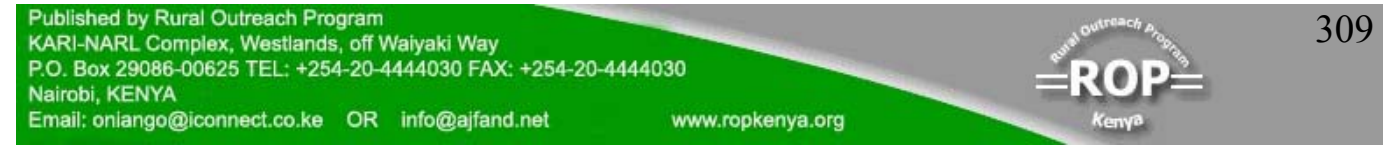


Figure 2: The loss of soybean during dehulling in relation to the steaming time $\left(\operatorname{Lsd}_{\mathrm{p}=0.05}\right)$.

(Lsd-Least significant difference)

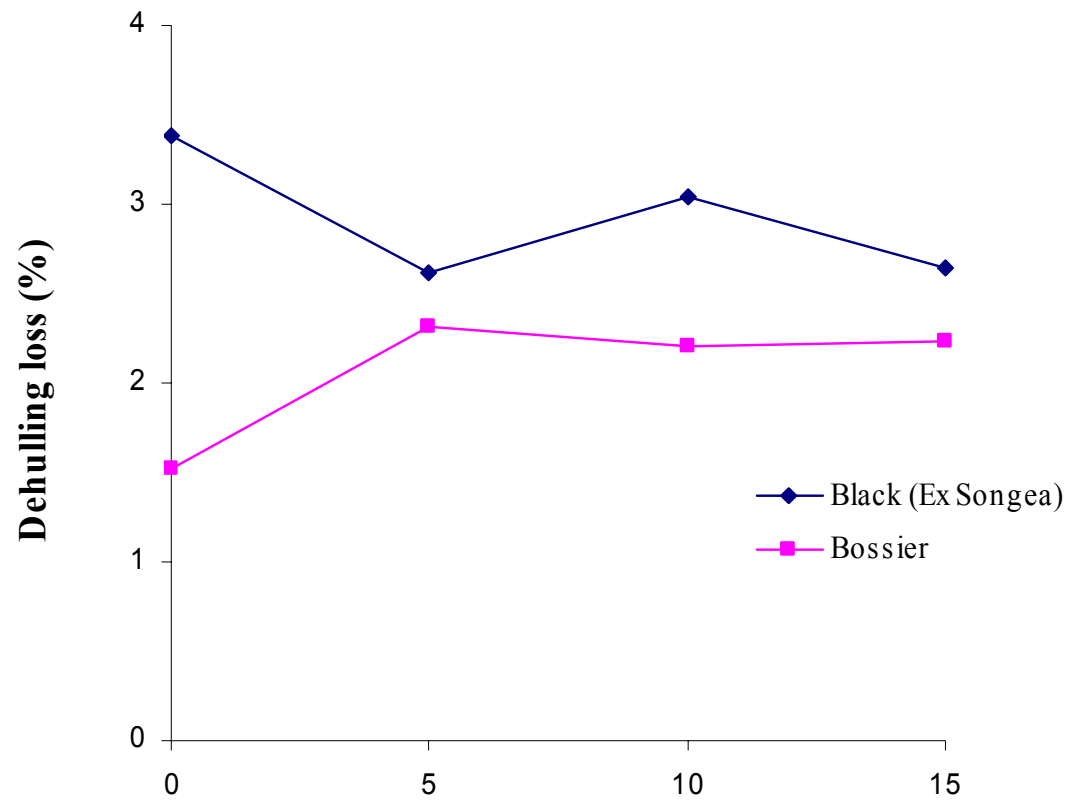

Steaming time (Minutes)

The relationship between steaming time (minutes) and dehulling is shown in Figure 3. The dehulling effectiveness index $(\eta)$ was 0.57 for Black (Ex Songea) soybeans and 0.68 for Bossier soybeans at no steaming. The results indicated that steaming by 5 , 10 , and 15 minutes led to dehulling effectiveness index $(\eta)$ of $0.78,0.86$ and 0.91 for Black (Ex Songea) soybeans and 0.78, 0.89 and 0.92 for Bossier soybeans. 
Figure 3: Effectiveness of dehulling operation as influenced by steaming conditioning of soybeans.

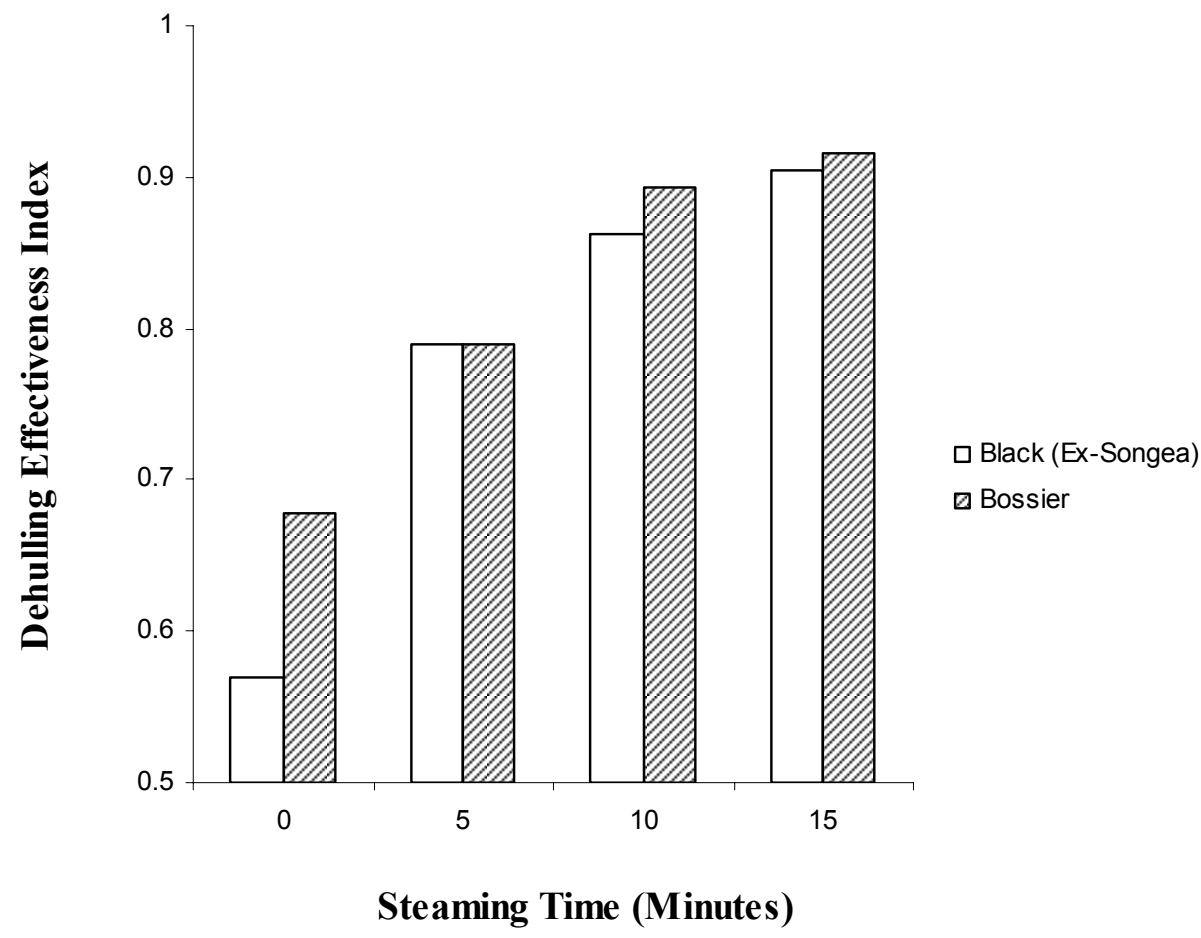

\section{DISCUSSION}

The average bulk density, moisture content, oil content and weight per grain of Black (Ex Songea) and Bossier varieties soybean were within the normal range for soybeans as suggested by Trabelsi et al. [16]. Similarly, although the oil content (moisture free basis) of Bossier soybean variety was slightly higher (20.21\%) than for the Black (Ex Songea) variety $(18.36 \%)$, both compared favourably with values reported in literature [17].

The results obtained showed that steaming of soybeans led to higher outturn for both Bossier and Black (Ex Songea) variety when compared to unsteamed (control) soybeans. The Bossier variety had a significantly $(\mathrm{P}<0.05)$ higher percentage of outturn before steaming of $74.75 \%$ compared to $68.35 \%$ for the Black (Ex Songea) variety. Results showed that there was a significant $(\mathrm{P}<0.05)$ improvement in the outturn after 5 minutes of steaming for both varieties. For example, at 5 minutes of steaming, cotyledon fraction increased from 68.35 to $79.40 \%$ for Black (Ex Songea)

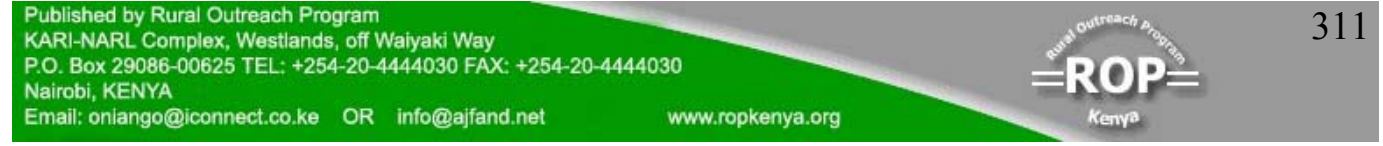


variety and 74.75 to $79.85 \%$ for the Bossier variety. It is likely that steaming of soybeans followed by solar drying rendered hulls brittle, which led to the easiness in removing them under the continuous application of abrasive forces. For unsteamed soybeans, the outturn was lower as the hulls and the cotyledons are likely to have had similar moisture content, which led to the difficulties in hull removal because it clung to the cotyledons. The process of thermal wetting during steaming is likely to have weakened the bonding materials holding the hulls to the surface of the cotyledons, thus freeing the hulls.

However, there was no significant difference $(\mathrm{P}<0.05)$ between the outturn fractions in soybean steamed for 10 minutes and that steamed for 15 minutes. The outturn fraction only increased marginally from $83.75 \%$ to $85.40 \%$ for the Bossier variety and from $82.10 \%$ to $82.20 \%$ for the Black (Ex Songea) variety when the time of steaming was changed from 10 to 15 minutes respectively. This suggested that steaming soybeans beyond 10 minutes was not necessary in as far as the yield of cotyledons was concerned and did not justify extra time and energy costs involved.

The undehulled fraction was higher at $18.80 \%$ for the Black (Ex Songea) variety compared to $14.75 \%$ for the Bossier variety as shown in Table 2. For soybeans steamed at 5 minutes, the undehulled fraction was significantly $(\mathrm{P}<0.05)$ reduced to $8.50 \%$ and $8.70 \%$ for the Black (Ex Songea) and Bossier varieties, respectively. Steaming beyond 10 minutes did not significantly $(\mathrm{P}>0.05)$ reduce the undehulled fraction although it tended to be more beneficial for the Black (Ex Songea) variety as compared to Bossier variety. The high level of undehulled beans for the Black (Ex Songea) variety can be attributed to the fact that Black (Ex Songea) beans were lighter with low bulk density, which caused them to bump around the dehuller cups as they were being dehulled and thus did not exert as much pressure on the sand paper surface in the dehuller. This led to a higher percentage of Black (Ex Songea) variety soybeans to escape undehulled, especially when no steaming was done.

The hulls and fines fractions are also indicated in Table 2. The results show that the hulls fraction increased with increasing steaming time, which corresponded to the increase in the outturn and the overall dehulling effectiveness. The hulls fraction increased from $8.90 \%$ for the unsteamed Black (Ex Songea) soybeans to $11.65 \%$ for soybeans steamed for 15 minutes. There was no significant increase in the hulls fraction in the Bossier variety when steamed beyond 5 minutes. Similar trends were observed in the fines fraction, showing an overall increase with steaming time. The increase in the amount of hulls and fines as a result of steaming may be due the soybeans becoming rather brittle and crushed during the dehulling process.

Results in Fig. 2 shows that overall, the materials (weight) loss during dehulling were low. However, the Black (Ex Songea) variety consistently showed slightly higher loss compared to Bossier variety. Fig. 2 also shows that there was a significant difference $(\mathrm{P}<0.05)$ in the weight loss between Black (Ex Songea) and Bossier variety when samples were not steamed and after steaming for 10 minutes. However, those varietal

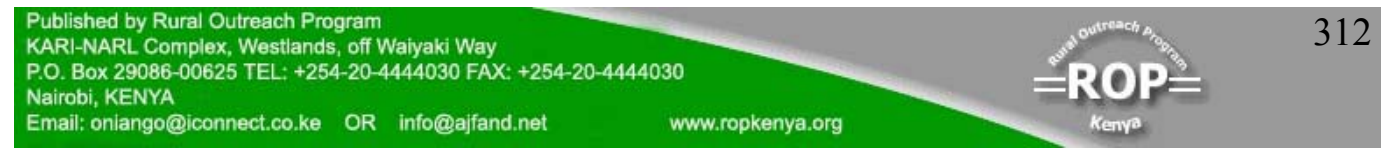


differences tended to fade away as soybeans were steamed. On steaming for 5, 10 and 15 minutes followed by solar drying, the difference was not significant. These results indicate that in the cases of longer steaming durations, the hulls and cotyledons tend to become more brittle on drying thus leading to formation of more lightweight particles. These are easily blown away by the moving air circulating inside the TADD dehuller which is generated by the fan rotated by the dehuller's rotor.

The dehulling effectiveness expressed in terms of the dehulling effectiveness index $(\eta)$ was affected by both steaming time and the soybean varieties as shown in Fig. 3. According to the results, unsteamed soybeans resulted in significantly lower $(\mathrm{P}<0.05)$ dehulling effectiveness index of 0.57 for Black (Ex Songea) soybeans variety and 0.68 for the Bossier soybeans variety as compared to 0.79 for both Black (Ex Songea) and Bossier soybean variety after undergoing steaming for 5 minutes. Further increase in steaming time increased the fines fraction which could be attributed to the brittleness in the soybean which leads to finer particles during dehulling hence more fines.

There was also a noticeable difference in the dehulling effectiveness index for the soybeans steamed for 10 minutes between the two soybean varieties with the dehulling effectiveness index $(\eta)$ of 0.86 for Black (Ex Songea) soybeans and 0.89 for Bossier variety. However, the varietal difference tended to decrease as the steaming time was increased to 15 minutes with Black Ex Songea soybeans attaining a dehulling effectiveness index $(\eta)$ of 0.91 as compared to 0.92 for Bossier variety. Results in Fig. 3 indicate that steaming had a direct effect on the physical dehulling characteristics of both Bossier and Black (Ex Songea) soybeans hulls during the brief steaming period, which tended to level out under prolonged steaming. Similar results were observed in previous studies $[11,12]$, in which it was shown that heat treatment makes cotyledons resilient or plastic, making the seed coat brittle and easily break when distorted by abrasive surface. On the other hand, drying tends to increase the brittleness of the hulls and hence becoming easier to remove. However, since prolonged heat uptake during steaming can affect the chemical composition of the soybeans, it is worth considering a short steaming time that leads to statistically similar dehulling effectiveness as this will also save energy. Further heat treatment of the cotyledons can then be applied to inactivate some of the unwanted enzymes.

\section{CONCLUSION}

The study has shown that simple steaming results in a significant improvement on the dehulling of soybeans. Steaming of soybeans led to better dehulling characteristics in both varieties. The dehulling effectiveness index $(\eta)$ of the method used in dehulling soybeans increased with increasing steaming time and levelled off after 10 minutes of steaming. This suggested that the most appropriate steaming times for both Bossier and Black (Ex Songea) soybean is between 5 and 10 minutes. Bossier soybean varieties showed high efficiency percentage compared to Black (Ex Songea) varieties. The study indicates that dehulling soybeans without steaming tended to account for higher material loss. Likewise, steamed Black (Ex Songea) soybeans had high

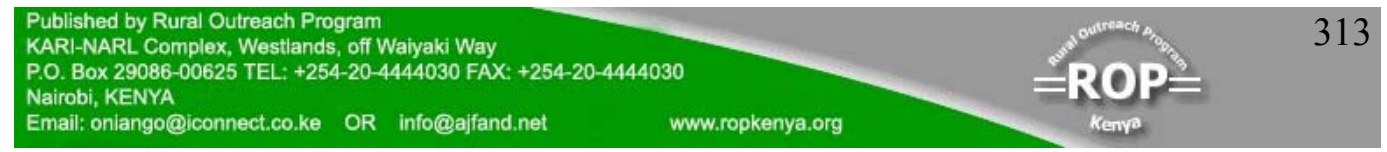


percentage loss compared to Bossier soybeans. This tested steaming method is simple and can be applied in rural areas to improve the processing of soybeans prior to dehulling and utilization. There is need to develop simple technologies that will use steaming as a preconditioning method to assist in the removal of hulls from soybeans at small scale level, which remains a major problem among small scale processors. This will further accelerate the production of soybeans by small scale farmers for both household consumption and income generation.

\section{ACKNOWLEDGEMENT}

The financial support from the Future Opportunities and Challenges in Agricultural Learning (FOCAL) program at Sokoine University of Agriculture (SUA), Morogoro, Tanzania is highly appreciated. Authors wish to thank Messrs John Waduma and Thadeus Ngonyani the Senior Technicians of the Food Science and Technology Laboratory, Sokoine University of Agriculture for assisting in the dehulling of samples. 
Table 1: Average bulk density, moisture content, oil content and weight per grain of Black (Ex Songea) and Bossier varieties (Ex-Songea) soybean.

\begin{tabular}{lcccc}
\hline Variety & $\begin{array}{c}\text { Bulk density } \\
\left(\mathrm{kg} / \mathrm{m}^{3}\right)\end{array}$ & $\begin{array}{c}\text { Moisture content } \\
(\% \text { wet basis })\end{array}$ & $\begin{array}{c}\text { Oil Content } \\
(\%)\end{array}$ & $\begin{array}{c}\text { Weight per grain } \\
\end{array}$ \\
\hline Black (Ex Songea) & 738 & 12.76 & 18.36 & 1.45 \\
Bossier & 789 & 12.25 & 20.21 & 1.94 \\
\hline
\end{tabular}


Table 2: Specific descriptive analyses of the dehulling experiment showing the cotyledon fraction (\%) outturn and undehulled, hulls and fines fractions for both Black (Ex Songea) and Bossier soybean variety

\begin{tabular}{|c|c|c|c|c|c|}
\hline Variety & $\begin{array}{l}\text { Steaming } \\
\text { time } \\
\text { (Min) }\end{array}$ & $\begin{array}{c}\text { Cotyledon } \\
\text { Fraction } \\
(\%)\end{array}$ & $\begin{array}{c}\text { Undehulled } \\
\text { fraction } \\
(\%)\end{array}$ & $\begin{array}{c}\text { Hull } \\
\text { fraction } \\
(\%)\end{array}$ & $\begin{array}{c}\text { Fines } \\
\text { fraction } \\
(\%)\end{array}$ \\
\hline \multirow[t]{4}{*}{ Black (Ex Songea) } & 0 & $68.35^{\mathrm{a}}$ & $18.80^{\mathrm{a}}$ & $8.90^{\mathrm{a}}$ & $0.57^{\mathrm{a}}$ \\
\hline & 5 & $78.40^{\mathrm{b}}$ & $8.50^{\mathrm{c}}$ & $9.70^{\mathrm{a}}$ & $0.79^{b}$ \\
\hline & 10 & $82.10^{\mathrm{c}}$ & $4.45^{\mathrm{d}}$ & $9.55^{\mathrm{a}}$ & $0.86^{\mathrm{c}}$ \\
\hline & 15 & $82.20^{\mathrm{c}}$ & $2.60^{\mathrm{e}}$ & $11.65^{\mathrm{b}}$ & $0.91^{\mathrm{c}}$ \\
\hline \multirow[t]{4}{*}{ Bossier } & 0 & $74.75^{\mathrm{b}}$ & $14.75^{\mathrm{b}}$ & $8.30^{\mathrm{a}}$ & $0.68^{\mathrm{ab}}$ \\
\hline & 5 & $79.85^{\mathrm{b}}$ & $8.70^{\mathrm{b}}$ & $8.35^{\mathrm{a}}$ & $0.79^{b}$ \\
\hline & 10 & $83.75^{\mathrm{c}}$ & $3.40^{\mathrm{de}}$ & $9.75^{\mathrm{a}}$ & $0.89^{\mathrm{c}}$ \\
\hline & 15 & $85.40^{\mathrm{c}}$ & $2.30^{\mathrm{e}}$ & $9.15^{\mathrm{a}}$ & $0.92^{\mathrm{c}}$ \\
\hline
\end{tabular}

${ }^{1}$ Mean separation by Duncan Multiple Range Test. Means with a common letter in the same column are not significantly different at $5 \%$ level of significance. 


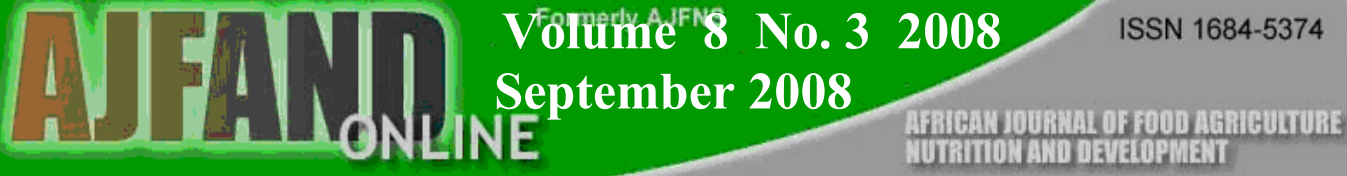

\section{REFERENCES}

1. IDRC. Selling Soybeans in Africa. International Development Research Center. http://www.idrc.ca/en/ev.26987. Visited November 2006.

2. FAO. United Nations Food and Agriculture Organization, Production Yearbook. FAO, Rome 1994, 48.

3. Garrow JS and WPT James (Eds) Human Nutrition and Dietetics. $9^{\text {th }}$ Ed. Churchill Livingstone, Edinburgh. 1993. p786.

4. Phirke PS and NG Bhole The effect of pre-treatment on the strength and dehulling properties of pigeonpea grain. Int. J. Food Sci. Tech. 1999, 34, 107 113.

5. Lazaro EL, Favier JF and SM Mpanduji Discrete element modelling of the abrasive dehulling process of sorghum and millet. Uhandisi (Engineering) Journal, 2002, 25, 6- 20.

6. Reichert RD, Tyler RT, York AE, Schwab BDJ, Tatarynovich JE and MA Mwasaru Description of a production model of Tangential Abrasive Dehulling Device and its application to breeders samples, Cereal Chemistry. 1986. 63: 201-207.

7. Thakor NJ, Sokhansanj S, McGregor I and S McCurdy Dehulling of canola by hydrothermal treatments. J. Am. Oil. Chem. Soc. 1995. 72: 597-602.

8. Singh $\mathbf{D}$ and $\mathbf{S}$ Soskhansanj Cylinder concave mechanism and chemical pretreatment for dehulling pigeon pea. Agric. Mech. Asia, Africa and Latin America, 1984. 15, 53-58.

9. Paulsen MR Fracture resistance of soybean to compressive loading. Trans. Am. Soc. Agric. Eng. 1978, 21, 1210 - 1216.

10. Ethiwe AOE and RD Reichert Variability in dehulling quality of cowpea, pigeonpea and mung bean cultivars determined with the tangential abrasive dehulling device. Cereal Chemistry. 1987, 64, 86-90.

11. Shyth BJ, Rodda ED and AI Nelson Evaluation of new soybean dehuller. Trans. Am. Soc. Agric. Eng. 1980, 23: 230-234.

12. Bekki $\mathbf{E}$ and $\mathbf{O R}$ Kunze Flash drying and milling techniques for high moisture brown rice. Trans. Am. Soc. Agric. Eng. 1988. 31, 1828-1834. 
13. Oomah BD, Reichert RD and CG Young A novel multi sample tangential abrasive dehulling device. Cereal Chemistry. 1981. 58, 392-395.

14. AOAC. Official Methods of Analysis. $16^{\text {th }}$ Edn. Association of Official Analytical Chemists, Washington D.C., 1995.

15. Ikebudu JA, Sokhansanj S, Tyler RT, Milne BJ and NS Thakor Grain conditioning for dehulling of canola. Can. Agric. Eng. 200042 (1).

16. Trabelsi S, Kraszewiski AW and SO Nelson Microwave dielectric sensing of bulk density of granular materials. Meas. Sci. Technol. 2001, 12: $2192-2197$.

17. Langenhoven ML, Kruger M, Gouws E and M Faber Food Composition Tables. Third edition. South African Medical Research Council. 1991. 227 pp. 